\title{
Organizational Intelligence
}

\section{Ontological Modeling of Skills}

\author{
https://doi.org/10.3991/ijac.v13i1.10589 \\ Najima Daoudi $(\bowtie)$ \\ Ecole des Sciences de l'Information (ESI), Rabat, Morocco \\ daoudinajima@yahoo.fr \\ Majda Nabigh \\ Conservatoire National des Arts et Métiers, Paris, France \\ Imane Hilal, Hasnae Rahimi, Fatima Zahra Atiki \\ Ecole des Sciences de l'Information (ESI), Rabat, Morocco
}

\begin{abstract}
In both the private and public sectors, human resource management processes face considerable challenges in terms of skills management within organizations. In fact, during the recruitment process, it is difficult to find the right profile for certain functions. To cope with this constraint and thus streamline this process, organizations tend to implement intelligent management of jobs and skills. Most systems of matching a job with a profile face the difficulty of developing and maintaining resources specific to each field. In view of this, ontologies are not only a tool for professional management and strategic management of human resources, but they also make it possible to base the relationship between the couple job / profile. Thus, we propose a construction approach of three ontologies that will play a key role in knowledge management in the context of the Secrétariat Chargé De L'eau but which remains valid for later use in broader contexts.
\end{abstract}

Keywords - Organizational intelligence; knowledge management; ontologies; Menthontology, skills management

\section{$1 \quad$ Introduction}

Currently, organizations aim to tackle the problem of Profiles inconformity during recruitment process. That's why they tend to adopt intelligent approaches to confirm the needed skills for a specific job. Thus, they ought to monitor their external environment and capitalize on their internal knowledge. To achieve the desired level of recruitment maturity, organizations implement customized and appropriate methods and tools.

The capitalization of knowledge and know-how is of crucial importance in organizations and already finds a place in the private sector. However, the public sector remains far from the use of this managerial practice. Accordingly, this work focuses on one hand on organizational intelligence in both public and private sectors. On the other 
hand, the paper exploits ontologies for the capitalization of knowledge in the public sector for the skills management purpose. In order to understand this problematic issue, we will dedicate the second section of this paper to the fundamental concept of our research which is the organizational intelligence. Then, we will focus on the Knowledge Management (KM) component. Next, we will present the concept and objectives of ontologies, which are used in several domains for different purposes including the management of competencies within organizations. The result of our research presented in the fifth section represents the ontologies of skills management built for the benefit of the KM component applying to the Menthontology methodology.

\section{Background and Definitions}

\subsection{Organizational intelligence}

D. Levinthal and J. March [1] present the intelligence of an organization as "the cognitive activity that improves the analytical and informational foundations of organizational action".

In fact, organizational intelligence can be considered as a new managerial practice at the service of the company's strategy that improves its creativity and ability to act. M. Feldman and J. March [2] consider that the intelligence of the organization is "the ability to provide, analyze and retrieve the right information at the right time". In this logic, organizational intelligence is a process that provides strategic information to the organization.

Information and knowledge management have a considerable impact on the administrative lifecycle of organizations. Internal and external information management flows influence not only administrative but also economic life. However, in a more dynamic environment, standards are accumulating, and technologies are continuously developing. As a result, it is important for both public and private organizations to monitor changes at the international and national environment maneuvering internal and external components. This monitoring is hence for the benefit of knowledge management strategy adopted by organizations. Baumard et al. [3] state that "organizational intelligence is a process that provides strategic information to the organization. It durably modifies its world view, its interactions with the environment and leads to the reorganization of its strategic intentions in order to reduce the difference between the real environment and the environment perceived in the strategy".

Indeed, the intelligence of an organization is not limited to the ability to learn and understand its environment, but mainly includes the ability to act. In the same perspective, Achard et al. [4] explain that the concept of intelligence is about the ability to analyze complex problems more or less quickly as the ability to synthesize and create new knowledge.

In this paper and inspired from the definitions abovementioned, we consider organizational intelligence as the analytical capacity that guides action towards a defined goal. This power of action and reaction is the result of Economic Intelligence (EI) and 
$\mathrm{KM}$ which are a managerial practice that builds and installs the intelligence of organizations.

\subsection{Knowledge management}

As mentioned earlier, organizational intelligence is merely based on EI and KM both relying on the same collective cognitive abilities. In fact, EI and KM represent tools and collective procedures that aim to establish the learning process that transforms information into actionable knowledge.

First of all, EI is a part of a systematic process of collecting, processing, disseminating and preserving information and knowledge. Then, KM maximizes the usefulness of the EI process through the capitalization and consolidation of knowledge and skills. Thus, EI and KM complement each other to build a strategic information and knowledge management based on a cross-dissemination and decompartmentalization of relations exploiting economic actors of the company. The purpose of these two processes is to gain a lasting competitive advantage and improve the intelligence of an organization.

For Nonaka et al. [5], KM is "the ability of an enterprise as a whole to create new knowledge, to disseminate it within the organization and to make it take shape in the various products and services of the system".

In addition, J. Balley [6], describes the KM process as the activity of exchanging, sharing and disseminating the existing knowledge within the organization collaborators. Authors of this paper say that "consists in implementing mechanisms allowing everyone to access existing knowledge more quickly, which is in the form of a stock of information (databases, documentary databases, etc.) than in the form of knowledge incorporated into individuals and organizations (know-how, experience, competence, etc.)".

To sum up, KM can be defined as a systematic process that intends to improve the performance and learning within organizations by brainstorming and enhancing best practices and gathering all collaborators' experiences in the organization.

"Capitalizing on the company's knowledge means considering the knowledge used and produced by the company as a set of assets constituting capital, and earning interest on it that contributes to increasing the value of this capital" [7].

As one of the levers of organizational performance, KM is mainly a capitalizationand collaboration-based approach. However, companies produce and capitalize on values that are not always financially visible (predictable, accessible). The goals of KM are mainly economic, organizational and social.

In the literature, there are two most well-known approaches in the field of management: the collaborative and the capitalization approaches.

In practice, whatever the choice of employees' departure is, the KM is ultimately a mixed approach based on both approaches. In fact, capitalizing without collaborating is a waste of time leading to databases that no one uses. Similarly, collaborating without capitalizing leads to ephemeris knowledge and constant reinvention of the wheel. These two approaches are the main steps of the KM policy, which lead to successfully managing the flow of information and thus preserving the intangible capital of the company. 
Knowledge modeling consists of representing, on an external support, a set of knowledge in a formalized and architectural way. It relates both knowledge and skills management processes within an organization. As a result, an ontology is presented as a knowledge capitalization tool that automates the collection, management, storage and exploitation of data.

\subsection{Ontologies}

Ontology is a word used in different fields such as philosophy, linguistics and artificial intelligence. In philosophy, ontology is the fundamental branch of metaphysics, for example $[9,10]$. It consists of studying the being and the general properties of what exists. Aristotle has described ontology as "the science of being as a being" [9]. Ontology is the science that is concerned with determining the fundamental categories of beings as they exist. According to Sartre [10], "ontology is defined as the explanation of the structures of being of the existing taken as a whole and metaphysics as the questioning of the existence of the existing". That is, an ontology allows not only to define the existing beings but also to structure them together.

Similarly, the term ontology is used in information science to refer to the structured set of terms and concepts representing the meaning of an information field. The main goal of an ontology is to model a set of knowledge in a given domain in order to build a representative model of the concepts involved and the relationships relating them.

Gruber et al. [11], "ontology is an explicit specification of a conceptualization". It makes it possible to specify in a formal language the concepts of a domain and their relationships.

In the rest of the paper, we consider an ontology as a set of knowledge, structured according to concepts and relations between them. A specific language is used to represent ontologies in a given domain of knowledge.

M. Fernandez et al. [12] advocates the need to set precise objectives before the development of an ontology. The aim is to define the limits and use cases.

Generally, ontologies aim to provide a common language facilitating communication amongst people, between people and machines or amongst systems.

In this paper, we propose an ontology applied to human resources management that aims to:

- Install an effective management tool making in order to facilitate the management of the professional career of the different status.

- Define the right human structure to carry out the activity while respecting quality requirements.

- Master the portfolio of jobs administratively held which provides a better readability of these jobs and their evolution

- Identify employee's activities and tasks to determine responsibilities and areas of expertise.

- Facilitate the creation of work teams and eventually the resolution of skills' conflicts

- Avoid redundancies in the overall process of administration.

- Ensure a fair and efficient assignment of key activities / tasks among employees. 
- Provide protection against the tendency of some people to change their area of competence or influence regardless of the priorities of the administration.

- Exploit the ontology to generate statistical results of the employees' expertise areas and motivations.

- Determine employees' profiles who tend to change their skills' orientation unfollowing the organization's priority.

In the literature, several studies have focused on knowledge management using an ontological approach. As far as Morocco is concerned, we can cite the project of Kamal El Guemmat et al. [13] at Hassan II University in Mohammedia. The project consists of building an ontology for the public higher education in Morocco. The build ontology tends to respond to the recurrent questions asked by a typical university student. Ismail Jellouli [14], from the Faculty of Sciences Dhar Mehraz of Fes, has developed an ontology applied to tourism by structuring a set of sources from the web to provide the end user with an integrated answer built from these sources. In Algeria, a human resources project by Faouzia Amourache [15] consists of developing an ontology for the modeling of the semantic content of the CVs / job offers in terms of their acquired (CV) or required (job offer). The ontology allows their subsequent automatic reconciliation by distinguishing skills acquired from those required and by explaining the semantics of the relationship that may exist between the different fields of the competencies.

At the international level, we mention the works of Claude Moulin, Fathia Bettahar, Jean-Paul Barthès CNRS (France, 2007) [16] who worked on the development of an ontology describing knowledge of the field of social assistance as part of the e-government. Brisson Laurent [17] in his research project for the benefit of the Computer Science, Signals and System Laboratory of Sophia Antipolis (I3S) proposed in his research report an example of an ontology representing knowledge from family allowance services. The objective is to extract models that reflect the behavior of the beneficiaries and their relationship with the various interlocutors. A case similar to our project, based on the use of ontologies in the management of knowledge and skills identified in the project led by Christophe Roche, Charles Foveau and Samah Reguigui who worked on the implementation [18] in place of an ontology that allows both the clarification of the concepts related to the management of jobs and skills forecasting, the maintenance of skills, knowledge and job references. The ontology developed by this research team allows in particular the management of the information taking into account the terminology and meaning used by the organization's professions.

\section{Construction of Ontologies of Skill Management for the Profit of the Component KM: Case of the State Secretariat in Charge of Water}

The purpose of this section is to present the process that allowed us to build our ontology proposal for the benefit of the State Secretariat for Water from knowledge gathering to implementation.

Indeed, our project started from a set of questions that guided our thinking: 
- What are the managerial practices that must be put in place by the SEE to control its internal and external strategic information?

- How can the SEE deploy its resources to be smart?

- What will be the strategic and organizational contribution of an organizational intelligence device?

To provide answers to these questions, our project consisted in the elaboration of an ontology based on the method Methontology. The choice of this method is justified by the fact that it covers the entire development cycle of an ontology, from specification to maintenance. It is also applicable to several disciplines as presented in Table 1.

Table 1. Comparison of ontology development methods [19]

\begin{tabular}{|l|l|l|}
\hline \multicolumn{1}{|c|}{ Methodology } & \multicolumn{1}{c|}{ Development tools } & \multicolumn{1}{c|}{ Goal } \\
\hline Text-to-onto & KAON software platform & Model the linguistic domain \\
\hline Methontology & Proteger 2000, ODE & Modeling multiple domains semantically and syntactically \\
\hline Terminae & RFIEC9 platform & Model multiple domains syntactically \\
\hline
\end{tabular}

In this context, our proposal consists of designing three ontologies:

The first of which represents a generic model of the abstract level. It models and connects all concepts that can be derived from an administrative status.

The second ontology is the application of a branch of the first ontology in the field of hydraulic planning. It allows to present all sub-fields of competence, skills, trades and jobs that arise from a given area of expertise.

To complete the definition of a status within an organization, it is necessary to define its main mission as well as the tasks, activities and exercises that result from it. To do this, the design of the third ontology of task ontology type consists in specifying the missions of the trades specified in the second ontology.

Thus, the objectives of our ontologies can be summarized as follows [20]:

- The first one is descriptive. It consists in forming a knowledge base by modelling a body of knowledge in our field of study.

- The second is reasoning. It consists of making inferences and automatically generating knowledge using a set of rules.

To ensure the sustainability of our project, the versioning method should be applied. Versioning [21] consists in creating a new version of the ontology each time an object changes value.This approach has three major disadvantages:(1) the change of a simple attribute implies the creation of a new version of the ontology. Subsequently, it presents a problem of data redundancy.

\subsection{Ontological engineering method: Methontology}

This is a methodology that was designed by the team of the artificial intelligence laboratory of the Polytechnic University of Madrid.

We will use Methontology for the development of the three ontologies. Thus, we will first proceed to define the objectives of each ontology. Next, we will use the MOT- 
typed object modeling language and the software that implements it (MOTPlus) [22] for ontology design. For the realization phase, we based ourselves on the Proteger 2000 considered to be the tool most adapted to the ontological engineering method adopted. It allows to model several domains semantically (properties of objects, properties of data) and syntactically (classes, subclasses).

\subsection{Ontology specification}

The purpose of this ontology is to specify the concepts and variables to be considered when defining a status. This work consists of facilitating the management of the skills of the State Secretariat for Water:

- New recruits: To za. Indeed, the design of this ontology makes it possible to present the fields of competence, the subfields of competence, the skills, the trades, the positions and the jobs of the field of the hydraulic installation. The conceptual model of this ontology can be applied to all other areas of competence of the different directions.

In order to establish the mission / competence relationship, it seems necessary to set up a task ontology. It not only allows to model the tasks, the activities and the exercises attached to a mission, but also to ensure an exhaustive management of the different statutes. The conceptual model of this ontology can be applied to all the other missions of the different statutes.

\subsection{Ontology conceptualization}

The first phase of conceptualization is the development of a glossary of terms that encompasses all the concepts, instances and attributes that are potentially usable for the represented ontology, as well as their detailed descriptions in natural language. Tables 2, 3 and 4 illustrate, respectively, a portion of the glossary of generic ontology, domain and task terms. 
Table 2. Part of the glossary of generic ontology terms

\begin{tabular}{|c|c|c|}
\hline Term & Description & Synonyms \\
\hline $\begin{array}{l}\text { Secrétariat d'Etat chargé de } \\
\text { l'eau }\end{array}$ & $\begin{array}{l}\text { Lead actor who decides on the appointment, assignment, pro- } \\
\text { motion and skills transfer }\end{array}$ & \\
\hline $\begin{array}{l}\text { Gestion des } \\
\text { Connaissances }\end{array}$ & $\begin{array}{l}\text { Methodology to simplify and improve the process of sharing, } \\
\text { distributing, creating, acquiring and understanding the com- } \\
\text { pany's knowledge }\end{array}$ & $\begin{array}{l}\text { Knowledge } \\
\text { Management }\end{array}$ \\
\hline $\begin{array}{l}\text { Gestion des } \\
\text { Compétences }\end{array}$ & $\begin{array}{l}\text { Management mode that aims to improve organizational per- } \\
\text { formance and enhance human resources }\end{array}$ & \\
\hline Statut & Situation of fact, position relative to an organization & \\
\hline $\begin{array}{l}\text { Domaine de } \\
\text { Compétence }\end{array}$ & Set of skills directly reliant on their field & \\
\hline Compétence & Set of knowledge, expertise and soft skills & \\
\hline $\begin{array}{l}\text { Expérience } \\
\text { Professionnelle }\end{array}$ & Refers to the implementation of the competence & \\
\hline Profil & $\begin{array}{l}\text { Professionally, a profile is the combination of skills and } \\
\text { work experience }\end{array}$ & \\
\hline Diplôme & Document that corresponds to a predetermined training & Training \\
\hline Métier & $\begin{array}{l}\text { Corresponds to a practice and a knowledge recognized in the } \\
\text { professional world in the absence of any organization }\end{array}$ & \\
\hline
\end{tabular}

Table 3. Part of the glossary of domain ontology terms

\begin{tabular}{|c|c|c|}
\hline Term & Description & Synonyms \\
\hline $\begin{array}{l}\text { Aménagement } \\
\text { Hydraulique }\end{array}$ & $\begin{array}{l}\text { Area of competence corresponding to } \\
\text { the management of water resources }\end{array}$ & Water management \\
\hline Aménagement d'un barrage & $\begin{array}{l}\text { Sub-field of expertise that allows the } \\
\text { design, the construction and the } \\
\text { maintenance of a dam }\end{array}$ & \\
\hline Conception & $\begin{array}{l}\text { A competence that designates the way } \\
\text { we conceive things }\end{array}$ & Idea \\
\hline Réalisation & $\begin{array}{l}\text { Competence permitting to switch from } \\
\text { the design stage to the existing things }\end{array}$ & $\begin{array}{l}\text { Achievement, application, execu- } \\
\text { tion }\end{array}$ \\
\hline Entretien & $\begin{array}{l}\text { Competence which designates the ac- } \\
\text { tion of keeping, of maintaining in good } \\
\text { condition; works, expenses, materials } \\
\text { needed to achieve it }\end{array}$ & \\
\hline Chargé des études & $\begin{array}{l}\text { A job dedicated to the person who en- } \\
\text { sures the control, the steering and the } \\
\text { evaluation of the studies of hydraulic } \\
\text { management }\end{array}$ & \\
\hline Dessinateur & $\begin{array}{l}\text { Occupation of the person who practices } \\
\text { the art of drawing in architecture }\end{array}$ & \\
\hline Gestionnaire du parc d'engin & $\begin{array}{l}\text { Occupation of the person who manages } \\
\text { or participates in the management of } \\
\text { the materials park }\end{array}$ & \\
\hline
\end{tabular}




\begin{tabular}{|l|l|l|}
\hline Chargé des travaux technique & $\begin{array}{l}\text { Occupation of the person who provides } \\
\text { technical assistance to the various par- } \\
\text { ties involved in the execution of the } \\
\text { hydraulic planning studies }\end{array}$ & \\
\hline Gestionnaire de l'exécution & $\begin{array}{l}\text { Occupation of the person who controls, } \\
\text { manages and guarantees the perfor- } \\
\text { mance }\end{array}$ & \\
\hline Chargé de l'entretien & $\begin{array}{l}\text { Occupation of the person who main- } \\
\text { tains and follows up the work }\end{array}$ & \\
\hline
\end{tabular}

Table 4. Part of the glossary of terms of the task ontology

\begin{tabular}{|c|c|c|}
\hline Term & Description & Synonyms \\
\hline Aménagement d'un barrage & $\begin{array}{l}\text { Management process of the design, the } \\
\text { construction and the maintenance of a } \\
\text { dam }\end{array}$ & \\
\hline Recherche du site & $\begin{array}{l}\text { Research process allowing to study } \\
\text { consistency and soil materials for se- } \\
\text { lecting the most suitable soil }\end{array}$ & \\
\hline Etude & $\begin{array}{l}\text { Set of studies to calculate indicators } \\
\text { and dam design volumes }\end{array}$ & \\
\hline Réalisation & $\begin{array}{l}\text { Application process permitting to } \\
\text { switch from the design stage to the ex- } \\
\text { isting things }\end{array}$ & $\begin{array}{l}\text { Achievement, application, execu- } \\
\text { tion }\end{array}$ \\
\hline Entretien & Maintenance and monitoring process & \\
\hline Etude géologique & $\begin{array}{l}\text { Study the consistency and the water- } \\
\text { tightness of the soil }\end{array}$ & \\
\hline Etude topographique & $\begin{array}{l}\text { Delimits the watershed and establishes } \\
\text { contours }\end{array}$ & \\
\hline Etude géotechnique & $\begin{array}{l}\text { Study the consistency of building mate- } \\
\text { rials }\end{array}$ & \\
\hline Etude hydrologique & Volume calculation of water intake & \\
\hline Etude hydraulique & $\begin{array}{l}\text { Dimensioning of ancillary works (wa- } \\
\text { ter evacuator, water intake, bottom } \\
\text { drain) }\end{array}$ & \\
\hline Etude de stabilité & $\begin{array}{l}\text { Calculation of slip and rollover stabil- } \\
\text { ity }\end{array}$ & \\
\hline Terrassement & $\begin{array}{l}\text { Excavation work to reach the bedrock } \\
\text { (the good soil) }\end{array}$ & \\
\hline Dérivation provisoire & $\begin{array}{l}\text { Drift the water source to institute the } \\
\text { construction of the dike }\end{array}$ & \\
\hline Travaux d'exécution & Execution of different works & \\
\hline $\begin{array}{l}\text { Construction des ouvrages an- } \\
\text { nexes }\end{array}$ & $\begin{array}{l}\text { Construction of the water evacuator, } \\
\text { the water intake and the bottom drain }\end{array}$ & \\
\hline
\end{tabular}

In order to insert the concepts into their contexts, we proceeded to the classification of the concepts in hierarchical form. 


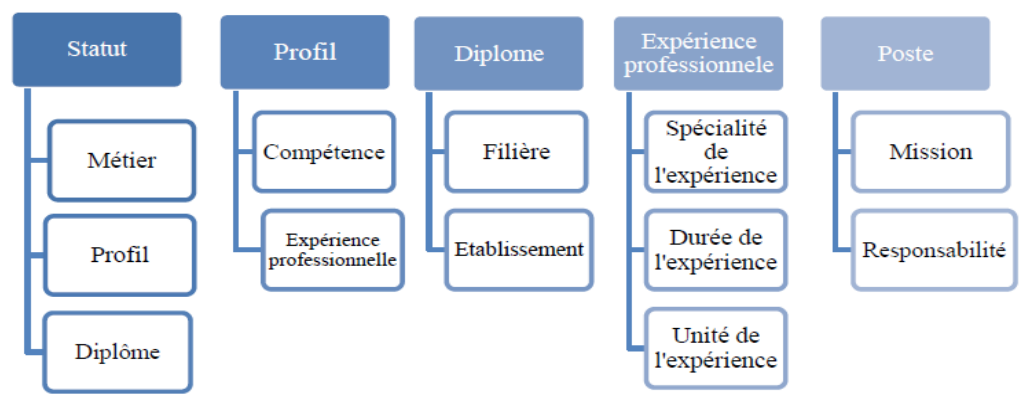

Fig. 1. Classification of generic ontology concepts in hierarchical form

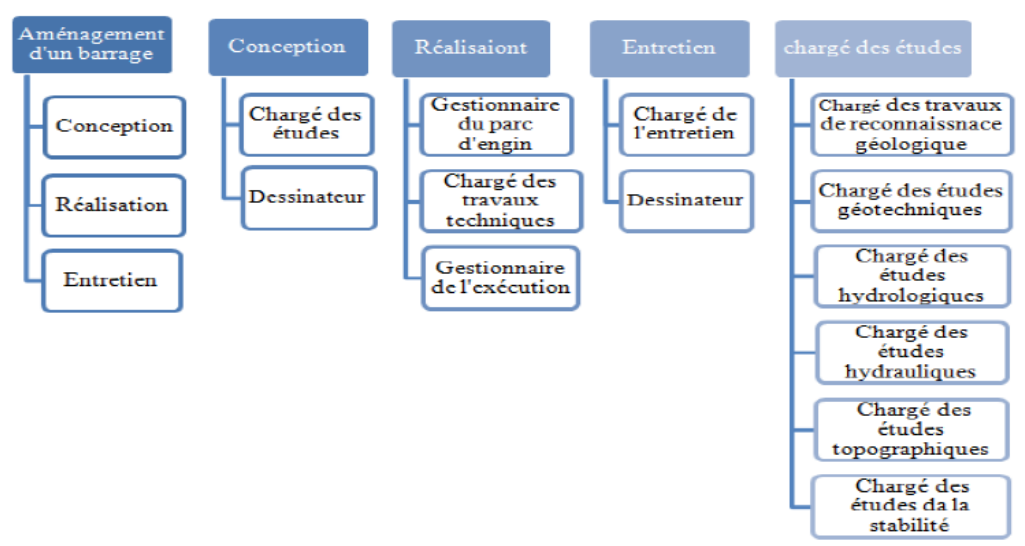

Fig. 2. Classification of domain ontology concepts in hierarchical form

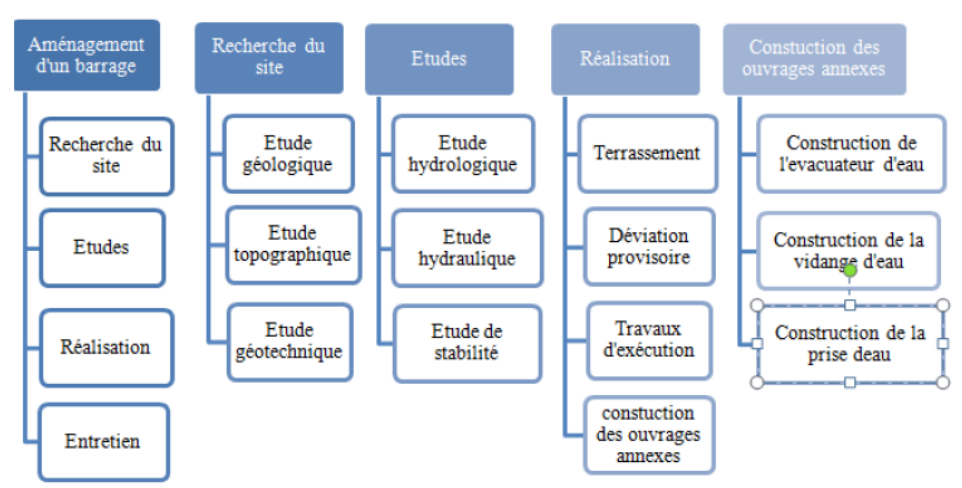

Fig. 3. Classification of the concepts of the task ontology in the hierarchical form 
After having prioritized the glossary terms, it was necessary to specify the properties that describe each concept of the hierarchy in a dictionary of concepts. The latter contains all the concepts of the domain, their attributes and their relations. Some are presented in Table 5.

Table 5. Extract from the generic ontology concept dictionary

\begin{tabular}{|l|l|l|}
\hline \multicolumn{1}{|c|}{ Concepts } & \multicolumn{1}{|c|}{ Attributes } & Relations \\
\hline & Name & \\
& Logo & \\
& Creation date & \\
Etablissement & Website & \\
& Phone number & \\
& Address & \\
& Legal status & \\
& Duration of training & \\
\hline \multirow{3}{*}{ Expérience professionnelle } & Specialty of the experience & \\
& Duration of the experience & \\
& Unit of the experience & \\
\hline
\end{tabular}

After the previous operations for the three ontologies, we proceeded to the definition of the concepts by means of logical expressions. For each axiom, it was necessary to specify the description of the axiom in natural language, the logical expression which formally describes the axiom in first-order logic, the associated concepts, the relations and the variables used.

Table 6. Table of axioms of generic ontology

\begin{tabular}{|c|c|c|c|c|c|}
\hline Concept & Description & $\begin{array}{l}\text { Expression } \\
\text { logique }\end{array}$ & $\begin{array}{l}\text { Concepts } \\
\text { Associés }\end{array}$ & Relation & Variable \\
\hline \multirow{2}{*}{ Compétence } & $\begin{array}{l}\text { *A skill is a set of } \\
\text { knowledge, know-how } \\
\text { and soft skills }\end{array}$ & $\begin{array}{l}\text { x skill }(\mathrm{x}) \Leftrightarrow \\
\text { knowledge }(\mathrm{x}) \cup \\
\text { know-how }(\mathrm{x}) \cup \\
\text { soft skills }(\mathrm{x})\end{array}$ & $\begin{array}{l}\text { knowledge, } \\
\text { know-how, } \\
\text { soft skills }\end{array}$ & $\begin{array}{l}\text { HasSavoir, } \\
\text { HasSavoir } \\
\text { faire, HasSa- } \\
\text { voir être }\end{array}$ & $\mathrm{X}$ \\
\hline & $\begin{array}{l}\text { *A skill may have one } \\
\text { or more occupations }\end{array}$ & $\begin{array}{l}\text { Pour y } \exists \text { x Compé- } \\
\text { tence }(x) \Leftrightarrow \text { compé- } \\
\text { tence }(x) \text {. has Mé- } \\
\text { tier }(y)\end{array}$ & Occupation & HasMétier & $x, y$ \\
\hline Métier & $\begin{array}{l}\text { *An occupation may } \\
\text { have one or more jobs }\end{array}$ & $\begin{array}{l}\text { Pour y } \exists \text { x Mé- } \\
\operatorname{tier(x)~} \Leftrightarrow \text { Mé- } \\
\operatorname{tier(x)} \text {. Has Em- } \\
\text { ploi(y) }\end{array}$ & Employment & Has-Emploi & $\mathrm{x}, \mathrm{y}$ \\
\hline
\end{tabular}

\subsection{Formalization of ontologies}

This phase constitutes the most tangible one. It makes it possible to visualize the location of the concepts relative to each other, as well as the relations which associate them. Figures 4 and 5 represent the formalization of the respectively generic, domain and task ontology used for the management of the knowledge and skills realized using the MOTPlus tool. 


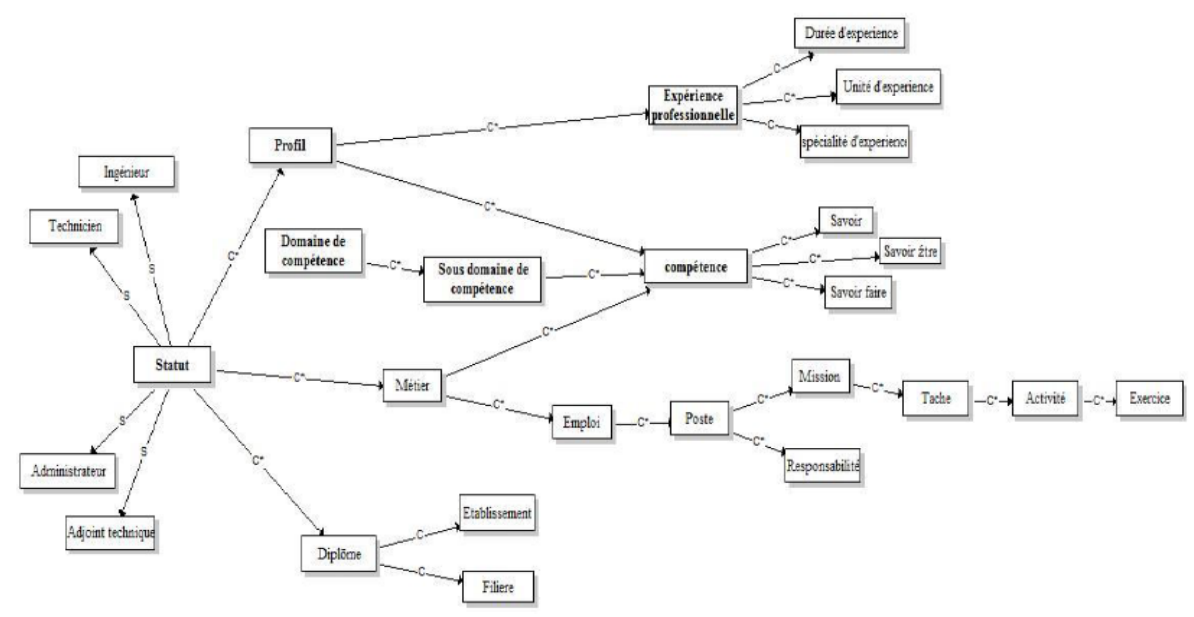

Fig. 4. Conceptual model of generic ontology

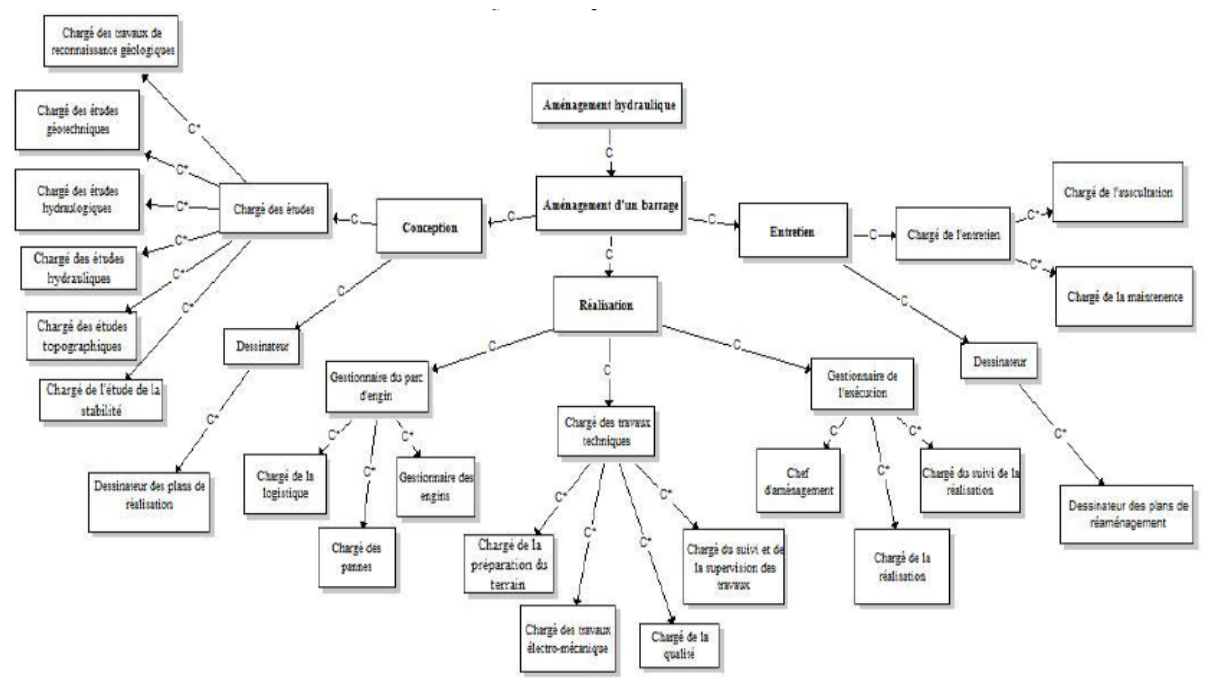

Fig. 5. Conceptual model of task ontology

The actual construction of the generic ontology consists in the realization of RDF schema of the ontology. To generate this schema, we used the Proteger 2000 tool.

The construction of the RDF schema took place in three phases:

- Creating classes and subclasses of the concepts described in the dictionary of concepts.

- Creating of the properties of the objects which consist in the linking of the classes and the predefined subclasses.

- Creating the attributes of each concept by specifying the data properties. 
In summary, the development of a knowledge capitalization policy through the implementation of three complementary ontologies facilitated the management of the statutes as well as their skills, their professions and their missions. The value of this project lies mainly in its ability to facilitate the management of skills in the long, medium and short term.

\section{Conclusion}

Through this article we have highlighted the proposals made in the margin of our study of the internal and external context of the Secretariat of State in charge of Water. A study that was also based on the analysis of the needs and expectations of the decision-makers of this organization, the recommendations of the specialized literature as well as on the best practices of the professionals of the field.

This work is a beneficial exercise that has allowed us to get hold of international knowledge engineering practices. It also represents a roadmap for the generalization of this experience to all the departments of the organization, which is the subject of the study.

This study certainly represents a proven interest. Our future work consists in enriching these ontologies with the aim of creating a system of automatic recommendation of skills for a greater capitalization of skills. In this sense we have already elaborated a state of art in the field of recommendation systems. We then intend to choose the most appropriate algorithm for our context to build the competence recommendation system and then link it to the ontologies that will be used as a basis for making the similarity between the required skills and those of the candidates.

\section{$5 \quad$ References}

[1] Levinthal, Daniel. A., March, James. G. (1993).The myopia of learning. Strategic Management.112 p. https://doi.org/10.1002/smj.4250141009

[2] Feldman, Martha. S. et March, James. G. (1991). L'information dans les organisations: un signal et un symbole, March, J.J (éd.), Décisions et organisations, Paris, éditions d'Organisation. $257 \mathrm{phttps://doi.org/10.4000/books.pufr.683}$

[3] Baumard. Phillipe, Stratégie et surveillance des environnements concurrentiels, Paris: Masson, $192 \mathrm{p}$

[4] Achard Pierre et Bernat Jean. Pierre. (1991). L'intelligence économique : mode d'emploi, adbse Edition.

[5] Nonaka et H. Takeuchi, La connaissance créatrice : la dynamique de l'entreprise apprenante. (1997). Bruxelle: de boeck.26 p.

[6] Balley, Jean-Francois. (2002). Tous managers du savoir: seule ressource qui prend de la valeur en la partageant, Paris: Ed. D'organisation, p.6.

[7] Grundstein, M. (2008). From capitalizing on Company Knowledge to Knowledge Management, chapter 12, in Knowledge Management, Classic and Contemporary Works by Daryl Morey, Mark Maybury, Bhavani Thuraisingham, The MIT Press, Cambridge, Massachusetts. $287 \mathrm{p}$. https://doi.org/10.7551/mitpress/4075.001.0001 
[8] Balmisse, Gill. (2002). Gestion des connaissances, outils et applications du Knowledge Management. Editions Vuibert. 150p.

[9] Aristote. Métaphysique, IV, 1, 1003 a

[10] Sartre .Jean-Paul. L’Etre et le Néant : essai d'ontologie phénoménologique .p 60.

[11] Gruber Thomas. R. (1993). Towards Principles for the Design of Ontologies Used for Knowledge Sharing in Formal Ontology in Conceptual Analysis and Knowledge Representation,. Kluwer Academic Publishers. p1.

[12] Fernández-López, M. and Gómez-Pérez, A. and Juristo, N. (1997). Methontology: From Ontological Art Towards Ontological Engineering. In: "aaai-97 Spring Symposium Series". Stanford University. EEUU.

[13] Kamal el guemmat, El habibb ben lahmar, moha ed Talea et al, La construction d'une nouvelle ontologie du domaine d'enseignement superieur public au maroc. 2012.

[14] Ismail Jellouli, Classification conceptuelle et ontologie de domaine pour l'intégration sémantique des données. e-TI, Revue électronique des Technologies de l'Information. http://www.revue-eti.net, Numéro 5. 2008. Issn 1114-8802

[15] Fouzia Amourache, Zizette Boufaïda, Leila Yahiaoui. (2008). Construction d'une ontologie basée compétence pour l'annotation des Cvs/Offres d'emploi. 10th Conference on Software Engineering and Artificial Intelligence (MCSEAI), Maghrebian Conference on Information Technologies. Algérie. pp.1-7.

[16] Claude Moulin, Fathia Bettahar, Jean-Paul Barthès et al, Extension d'ontologie favorisant la catégorisation et l'indexation sémantique. Disponible en ligne: https://projet.liris.cnrs.fr/gom/JFO 2007/17.pdf (Consulté le 16/01/2019)

[17] Laurent Brisson, Mesures d'intérêt subjectif et représentation des connaissances. Laboratoire Informatiques Signaux et Système Sophia Anapolis. (2004). Disponible en ligne: http://www.i3s.unice.fr/ mh/RR/2004/RR-04.35-L.BRISSON.pdf (Consulté le 16/01/2019)

[18] Christophe Roche, Charles Foveau, Samah Reguigui, La démarche ontologique pour la gestion des compétences et des connaissances. Disponible en ligne : https://editions-rnti.fr/render_pdf.php?p=1000299 (Consulté le 16/01/2019)

[19] Nabigh, Majda; Daoudi, Najima. (2018). Capitalization of Knowledge Through Ontologies: A Knowledge Management Approach in a Strategic Intelligence Process. In IEEE 5th International Congress on Information Science and Technology (CiSt). Marrakech. https: //doi.org/10.1109/CIST.2018.8596616

[20] Fatma Ghorbel (2018). Dialogue graphique intelligent, fondé sur une ontologie, pour une prothèse de mémoire. Bio-informatique [q-bio.QM]. Conservatoire national des arts et métiers - CNAM. Français.

[21] S. Batsakis, E. G. Petrakis, I. Tachmazidis et G. Antoniou, (2017). Temporal representation and reasoning in OWL 2", In: Semantic Web, 8(6), pp.981-100. https://doi.org/10.32 $\underline{33 / \mathrm{SW}-160248}$

[22] Michel Heon et al,Méthodologie assistée de conception d'une ontologie à partir d'une conceptualisation consensuelle semi-formelle. Pdf. Centre de recherche Licef, Télé-Université, Montréal, Canada. 3 p.

\section{Authors}

Najima Daoudi has been a Professor at the School of Information Sciences (ESI) since 2000. She is an Engineer of the National Institute of Statistics and Applied Economics and has a Ph.D. in Computer Science from ENSIAS. She is a member of IEEE 
and INNS. She has produced several articles in E-learning, M-learning and Ontology development since 2005. In February 2018, she co-authored the chapter "MOROCCO: E-learning in the Middle East and North Africa (MENA) region". ISBN 978-3-3-31968999-9. Publisher Springer International Publishing. N. Daoudi published in many important conferences like ICL2008, EDUCON 2018, IMCL 201, ICMCS 2018 and Niss'19. She participated in many conferences as Organising Committee or TPC such as: ngns'16, MISC18, SysCoBIoTS'2019, ArabWIC19. She is a general chair of ICSSD'2019 and ICSSD'2020 an IEEE international conference. Her areas of expertise include Artificial Intelligence, datamining, recommended system and ontology applicated in various domains.

Majda Nabigh is a young professional in the field of strategic watch and competitive intelligence. She has carried out several works in the field. She has also published a book during the consecration of the city of Rabat in Morocco as a heritage city by UNESCO. In 2011, she was awarded the first Moroccan prize for strategic intelligence and competitive intelligence. She is currently working on a thesis in international cosupervision ESI-CNAM, on the issue of territorial intelligence in the southern provinces of Morocco. E-mail: nabigh.majda@yahoo.fr

Imane Hilal holds a Dipl.-Ing. (MSc) from National School Of Computer Science And Systems (ENSIAS) in 2009. Then she spent more than eight years in teaching IT development to IT Specialized technician. In 2016 she got a Ph.D. degree from Hassan II University of Casablanca. Her research interests lie in various Computer Science Areas such as: Data Warehousing, Dependability, MDE, Elearning, Big Data, Cloud Computing. Currently, she is an Assistant Professor in the School of Information Sci-ences (ESI) and co-supervises several theses. She participated in many conferences as Organising Committee or TPC such as: ISI17, MISC18, ArabWIC19 and as Program Committees Chairs in ICSSD19 E-mail: imanehilal@gmail.com

Hasnae Rahimi is an Assistant Professor at the School of Information Sciences (ESI) in Rabat, Morocco since 2017. She holds a Ph.D. in Computer Science from the Superior National School of Computer Science and Systems' Analysis (ENSIAS) in 2017. She is also a Computer Science Engineer from the same school with a specialty in Business Intelligence. She is certified in Machine Learning and Decision-Making from the Massachusetts Institute of Technology Professional Education (MITPE). She participates in organizing and chairing several IEEE, ACM and Springer international conferences around the world. Prof. H. Rahimi has brought proven success in implementing technology-based curriculum delivery and assessment tools in the research lab, where she collaborates with experts in Machine Learning and Software programming. Her areas of expertise include Machine learning, Deep learning, Natural Language Pro-cessing, Sentiment Mining, Cloud Computing, and Trust and Reputation Management in e-services. hasnae.rahimi@gmail.com

Fatima Zahra Atiki is an engineer from the School of Information Science, Rabat, Morocco, in 2017.

Article submitted 2019-04-02. Resubmitted 2019-12-26. Final acceptance 2020-02-07. Final version published as submitted by the authors. 